clude those in the social sciences, life sciences, education, humanities, and professional programs such as library and archival sciences, social work, public administration, nursing, and public health.

The content of the test will focus on precollege algebra, basic geometry, and elementary statistics. There will be decreased emphasis on routine computation and algebraic manipulation, while the emphasis on data interpretation and reasoning will increase. As with the new Mathematical Reasoning Test, examinees will be required to generate their own response for some questions.

Revised Verbal Reasoning Test. The revised Verbal Reasoning Test will measure the ability of examinees to analyze and evaluate written material and synthesize information from it. There will be an increased emphasis on critical reading and the inclusion of context in test questions.

Most of the current question types-sentence completion, reading comprehension passages, ant- onyms, and analogies-will be included in the revised test, although the relative proportion is likely to change. Further, the introduction of new question types such as multiple-passage reading comprehension sets and synonyms in context is being investigated.

Revised Analytical Reasoning Test. The Analytical Reasoning measure is being revised to incorporate a greater emphasis on informal reasoning. Thus, the portion of the test that measures an examinee's ability to analyze and evaluate arguments, identify central issues and hypotheses, draw sound inferences, and identify plausible causal explanations is expected to increase. New question types that take advantage of the computer are expected to supplement the current question types.

\section{General Test Package Options}

Before the introduction of the new General Test, graduate schools and departments will need to select the package of measures that is most appropriate for students applying for admission to their particular program. The two packages are: Verbal, Analytical, Writing, and Quantitative Reasoning; or Verbal, Analytical, Writing, and Mathematical Reasoning.

It is important that graduate departments make this decision in concert with the publication deadlines for their graduate catalogs.

\section{Additional Information}

For more information about the new GRE General Test, please contact the GRE Program via telephone at (609) 951-1551 or via Internet at gre-info@ets.org.

\section{About the Author \\ Ann Willard is an associate program direc- tor, GRE Program, Educational Testing Service.}

\title{
International Forum for Democratic Studies Established by the National Endowment for Democracy
}

\author{
Marc F. Plattner and Larry Diamond, International Forum for Democratic Studies
}

Never has there been a time when understanding what helps or hinders the advancement of democracy around the world has been more critical for international peace, political stability, and human progress. The spread of democracy to many countries around the world has brought unprecedented freedom and opportunity to millions of people and has diminished the threat of war and other forms of violent conflict. At the same time, however, a number of authoritarian regimes remain firmly entrenched and many new democracies are functioning poorly, with questionable institutional designs and a daunting array of other political, social, and economic obstacles to consolidation.

In response to the need for sustained and serious study of democracy's problems and prospects, the National Endowment for Democracy (NED) established the International Forum for Democratic Studies in April 1994. The International Forum is a center for analysis and discussion of democratic ideas, experiences, theories, and practices worldwide. It will also serve as a clearinghouse for information on the varied activities and programs of groups and institutions working to achieve and maintain democracy around the world. Thus it will fill an important institutional void in the field of democratic studies at the same time that it complements and enhances the democratic programs of NED and other donor and civic organizations.

The Forum has initiated three interrelated programs: a research and conferences program, a Democracy Resource Center, and publication of an expanded Journal of Democracy. The Forum is also laying plans for a visiting fellows program that will enable a small number of distinguished scholars and democratic activists from around the world to spend three 
to ten months in residence at the Forum.

\section{Research and Conferences Program}

The Forum's research projects, conferences, and publications address both the practical and theoretical aspects of democracy and democratization. Research sponsored by the Forum focuses on issues of democratic transition and consolidation as well as the common challenges facing new and established democracies. The Forum's activities involve and benefit scholars, policymakers, and activists representing diverse experiences and views. While the Forum's focus and outreach are global, a portion of its program addresses the interests and needs of the Washington policy-making community.

The first conference sponsored by the Forum, held in Washington, D.C., in May 1994, analyzed the tensions and compatibilities between economic reform and democracy. The papers presented at this conference have been published in the October 1994 Journal of Democracy. Three additional conferences are now being planned on comparative themes: the causes and consequences of the almost universal decline of political parties, and strategies for building or rebuilding effective parties and party systems; civil-military relations and the consolidation of democracy; and Asian attitudes and approaches to democracy.

Other possible topics for future research projects and conferences include: political decentralization and its implications for local-level democracy; the management and reduction of ethnic and religious conflict in democracies; the role of civil society in developing democracy; strategies for controlling corruption and improving accountability; and Islamic approaches to democracy and the prospects for democracy in the Islamic world.

In addition to organizing major research projects and conferences, the Forum also sponsors smaller meetings on timely issues and particular countries or regions. In October the Forum held a day-long conference on the prospects for political liberalization in China. A meeting on the political crisis in Nigeria was held in early December. The goal of these meetings is to bring policymakers, scholars, and activists together to share information, discuss recent developments, and identify ways to strengthen democracy.

\section{The Democracy Resource Center}

The Democracy Resource Center (DRC), when fully operational, will consist of a library and archives, an electronic database, and an international "bulletin board" on democracy. The DRC will eventually house more than 10,000 titles and have a state-of-the-art electronic information center.

The library and archives will contain a collection of books, journals, and other publications on democracy, an assortment of materials used to build democracy around the world (such as newsletters, election manuals, voters guides, and civic education videos), documentation on NED-supported programs, and information on the activities of other democracy-building groups and organizations. An electronic database, accessible through the Internet, will contain information on organizations working to promote democracy and the bibliographic records of the library holdings. Planning is also underway for an electronic "bulletin board," also linked to the Internet, which will allow for the instantaneous exchange of information and views regarding democratic developments around the world. Examples of the types of information likely to be "posted" on the bulletin board include: news of the activities of prodemocracy groups and organizations; reports on recent conferences and meetings; announcements of new research projects, publications, and coming events and meetings; and requests for information and other forms of assistance.

\section{Publication of the Journal of Democracy}

The third component of the Forum is an expanded version of the Joumal of Democracy, the quarterly journal published for the $\mathrm{Na}$ tional Endowment for Democracy by Johns Hopkins University Press. Founded in 1990, the Journal has quickly become one of the most widely read and cited publications on the problems and prospects of democracy around the world. The Journal has been expanded from 144 pages per issue to 192 pages. This expansion allows the Journal to cover a greater number of countries and issues and to publish more reviews of the many new books dealing with democracy.

The Joumal of Democracy presents a range of authoritative and provocative views on issues central to democratic theory and practice. Each issue typically contains clusters of articles on key topics, regions, or countries, and entire special issues have been devoted to two topics: "Capitalism, Socialism, and Democracy" and "Democracy and Economic Reform." Selected articles from the Joumal have also been collected into three volumes edited by Larry Diamond and Marc F. Plattner and published by Johns Hopkins University Press: The Global Resungence of Democracy (1993); Capitalism, Socialism, and Democracy Revisited (1993); Nationalism, Ethnic Conflict, and Democracy (1994).

The Forum's programs will contribute to a better understanding of what helps and hinders the advancement of democracy. With this understanding, democratic political leaders and activists will be better able to select appropriate strategies and institutions for building democracy. Moreover, the Forum's ability to generate and disseminate information and analysis will make scholars around the world more aware of current research on democracy (and gaps in that research) and will improve education about democracy by increasing the resources and materials that can be used for instruction.

The International Forum is directed by Marc F. Plattner and 
Larry Diamond, who also coedit the Journal of Democracy. The Forum's programs benefit from the advice and involvement of a $\mathrm{Re}$ search Council consisting of U.S.based scholars and specialists, including many eminent political scientists.
For further information about the International Forum, contact David G. Timberman or Debra Liang, The International Forum for Democratic Studies, 1101 15th Street, NW, Suite 802, Washington, D.C. 20005, or call (202) 293-0300.

\section{About the Author}

Marc F. Plattner and Larry Diamond, senior fellow at the Hoover Institution, are codirectors of the International Forum for Democratic Studies, National Endowment for Democracy.

\section{The Other Game or the Rational Choice Approach to Football}

Editor's Note: This press release was submitted by Ian Shapiro, Department of Political Science, Yale University.

Most people know that on Saturday, November 19, the Yale Bulldogs trounced the Harvard Crimson in Cambridge by a stunning 32-13. Fewer people are aware that on the same day another equally impressive football defeat was handed to Harvard by Yale. Reviving a long defunct tradition, the Faculty of the Yale Political Science Department took on the Harvard Government Department, beating them $26-8$ in a game that raised $\$ 300$ for charity.
Harvard won the toss. One of their veterans, Professor James Alt, immediately commented "There's one for rational choice," referring to the Harvard/Yale rivalry over political science models. [Yale quarterback Donald Green and lineman Ian Shapiro are coauthors of a recent Yale Press book, Pathologies of Rational Choice Theory, critiquing the Harvard approach]. Unfortunately for Alt and his fellow rational choosers, the toss was the last thing that went well for them. Impressive interceptions by Theordore Marmor, Cathy Cohen, and Douglas Rae led to a 12-0 halftime score. Linemen Shapiro, Rae, and Avi Segal effectively harassed the Crimson at the line of scrimmage all day.

In the second half, wide receivers Doug Reed and Marty Gilens sealed the victory with two impressive touchdown receptions from quarterback Green, and the Yale team coasted to victory, despite a Harvard touchdown and impressive two-point conversion from Harvard quarterback Michael Hagen in the closing seconds. Yale MVP Cohen, playing as wide receiver, defensive back, and punt returner, ran rings around the Harvard offense. Several Harvard players were overheard after the game wondering why their rational strategy had not paid off. 